\title{
Influence of altered light conditions and grazers on Scrippsiella trochoidea (Dinophyceae) cyst formation
}

\author{
Veronica Lundgren*, Edna Granéli \\ School of Natural Sciences, Linnaeus University, Kalmar, Sweden
}

\begin{abstract}
We investigated whether or not the presence of copepods and different light conditions induced cyst formation in dinoflagellates. Scrippsiella trochoidea was exposed to Acartia tonsa directly and indirectly (grazer filtrate), in high light and low light conditions. The ingestion, faecal production and egg production of $A$. tonsa were compared between diets of $S$. trochoidea vegetative cells and temporary cysts. We found no effect of direct or indirect exposure to A. tonsa on $S$. trochoidea cyst formation in either high light or low light conditions. Controls and $A$. tonsa treatments kept in light displayed around $20 \%$ temporary cysts, whereas controls and A. tonsa treatments in low light were shown to have 50 to $80 \%$ temporary cysts. Thus, low light conditions had a strong effect on temporary cyst formation. No hypnocysts were observed in any experiment, which is probably related to the longer incubation times needed for their observation. Feeding on diets dominated by temporary cysts compared to vegetative cells decreased ingestion by a factor of 2.7 , while faecal and egg production decreased by a factor of 2.2 and 2.9, respectively, suggesting that induction of temporary cysts in response to $A$. tonsa could be a survival strategy. However, $S$. trochoidea does not possess any grazer-induced defence in terms of temporary cyst formation, as it did not produce temporary cysts when exposed to A. tonsa. Rather, induction of temporary cysts seems to be controlled by decreased light intensity, which is a favorable trait for this species when driven to water depths where light is scarce.
\end{abstract}

KEY WORDS: Scrippsiella trochoidea $\cdot$ Cyst formation $\cdot$ Light intensity $\cdot$ Grazer density $\cdot$ Temporary cysts

\section{INTRODUCTION}

Cyst formation is a common feature of many dinoflagellate species. Resting cysts or hypnocysts are surrounded by persistent cell walls and result from sexual processes. Temporary cysts are formed from vegetative cells by ecdysis, and are surrounded by a pellicle (Anderson \& Wall 1978, Pfiester \& Anderson 1987).

Hypnocyst formation is a response to a variety of detrimental environmental factors, such as nutrient limitation (Anderson et al. 1984, Imai 1989, Figueroa et al. 2006), changes in temperature (Hardeland 1994), salinity (Zonneveld \& Susek 2007), day length (Sgrosso et al. 2001), light intensity (Imai 1989), iron stress (Doucette et al. 1989), and high vegetative cell densi- ties (Garcés et al. 2004). After a certain maturation period, resting cysts could function as a 'seed bank' for initiating new blooms when conditions are favourable again (Anderson 1997, Rengefors \& Anderson 1998).

Formation of temporary cysts has been regarded as a sampling (Garcés et al. 2002) or culture artefact, related to ageing of cultures (Jensen \& Moestrup 1997), nutrient stress (Anderson \& Wall 1978), bacterial attack (Nagasaki et al. 2000) or to changes in temperature (Grzebyk \& Berland 1996) and unfavourable light conditions (Rintala et al. 2007). However, there have been some observations of temporary cyst formation in situ (Garcés et al. 1998, Xiao et al. 2001) or in largescale mesocosm experiments (Olli 2004). Therefore, it has been suggested that temporary cysts are part of 
the natural life cycle of dinoflagellates (Garcés et al. 2002).

Although cyst formation in dinoflagellates is usually induced by adverse abiotic factors, cysts may also function as a defence mechanism against various biological threats, other than the bacterial attack mentioned above. For instance, Fistarol et al. (2004) have shown that Scrippsiella trochoidea significantly increased the production of temporary cysts in response to allelochemicals, which has also been confirmed in more recent studies (Tillmann et al. 2007, Tillmann \& Hansen 2009). Furthermore, Toth et al. (2004) have shown that Alexandrium ostenfeldii shifted from motile cells to temporary cysts in the presence of chemicals released from a parasite. Hypnocysts have also been speculated to be a defence against predation because of their shape and chemical constitution (Sarjeant et al. 1987). The same authors also concluded that cysts could escape predation by planktonic grazers by sinking out of the water column. Alternatively, if cysts are eaten, they can survive gut passage and show a high germination rate after passing through the digestive system of certain copepod grazers (Montresor et al. 2003). Some studies have revealed that grazers play a role in life history alterations of phytoplankton, such as excystment of hypnocysts, and that this is a way to minimize predation losses. In the presence of high numbers of grazers or infochemicals released by them, the raphidophyte Gonyostumum semen and the dinoflagellate Peridinium aciculiferum reduced the recruitment rate of hypnocysts from the sediment. By adjusting the timing of recruitment from the 'seed-bank', these algae could avoid being grazed (Hansson 1996, Rengefors et al. 1998). Some phytoplankton species are also able to respond to infochemicals released by zooplankton by adjusting other defensive traits, such as morphology (Hessen \& van Donk 1993, Tang 2003, Lundgren \& Granéli 2010) and toxin production (Jang et al. 2003, Selander et al. 2006), and thus these species become less vulnerable to grazing (Hessen \& van Donk 1993, Selander et al. 2006).

No studies have yet reported any effects of grazers or infochemicals released from grazing activities on encystment of temporary cysts or hypnocysts. Furthermore, little is known about the possibility of combined effects of grazers and abiotic factors, such as altered light conditions, on cyst formation in dinoflagellates. Light intensity in oceanic waters is subjected to great spatiotemporal variation depending on the position of the sun, the wavelength of light, cloud conditions, the optical properties of water, and the water depth (Hieronymi \& Macke 2010). In addition, the effects of global warming are expected to cause an increase in aerosol concentrations in the atmosphere, thus leading to a reduced amount of light reaching the earth's surface (Kulmala et al. 2003). Such fluctuations in light intensity will certainly have an effect on the growth and photosynthesis of phytoplankton, but may also affect the cyst formation of dinoflagellates (Imai 1989, Rintala et al. 2007).

One aim of the present study was to examine the combined effects of both direct and indirect (infochemically driven) exposure to copepods and altered light conditions on dinoflagellate cyst formation. A second aim was to investigate ingestion, and faecal and egg production of copepods to evaluate the food quality and potential defensive ability of vegetative cells, as well as temporary cysts, of dinoflagellates.

\section{MATERIALS AND METHODS}

We chose the dinoflagellate Scrippsiella trochoidea and the copepod Acartia tonsa as model species in this study. S. trochoidea is a cosmopolitan bloom forming species (Wang et al. 2007) and thus plays a significant role in ecosystem functioning across the world. Moreover, $S$. trochoidea was previously observed to form temporary cysts in response to allelochemicals in our laboratory (Fistarol et al. 2004) and we wanted to examine if such a mechanism would also occur in response to the presence of grazers (copepods) and/or low light conditions. A. tonsa was chosen due to culture availability at the time of the experiments. A. tonsa is also one of the most common copepod species in estuarine waters and can occur in areas such as the Chesapeake Bay (Purcell et al. 1994) where blooms of S. trochoidea have also been reported (Marshall \& Egerton 2009).

This study consisted of 2 experiments: the grazer exposure experiment and the grazing experiment. The grazer exposure experiment investigated direct and indirect effects of increasing Acartia tonsa densities on Scrippsiella trochoidea cyst formation in both high light and low light conditions. In the grazing experiment we examined ingestion, and faecal and egg production of $A$. tonsa on vegetative cells and temporary cysts of $S$. trochoidea.

Organisms and culture conditions. The algal bank at the University of Gothenburg (GUMACC) provided the Scrippsiella trochoidea strain used in the present study (strain: GUMACC 110). Rhodomonas salina, used as food for copepod cultures, originated from Kalmar Algal Collection (KAC, Linnaeus University, Kalmar, Sweden, strain: KAC 30). Phytoplankton medium for growth and maintenance of $S$. trochoidea cultures were prepared by autoclaving filtered (munktell glass fiber filters, mesh size: $1.2 \mu \mathrm{m}$ ) natural seawater from the Swedish west coast, after the salinity 
had been adjusted to $26 \mathrm{~g} \mathrm{~kg}^{-1}$ by addition of Milli-Q water. Media for the $R$. salina culture were prepared in the same manner, except that the water originated from the Baltic Sea and that $\mathrm{NaCl}$ was added to obtain a salinity of $26 \mathrm{~g} \mathrm{~kg}^{-1}$. S. trochoidea and $R$. salina had been growing at this salinity prior to the experiments presented here. Nitrogen $(\mathrm{N})$ and phosphorus $(\mathrm{P})$, as well as vitamins, were added at concentrations corresponding to F/2 medium, with $\mathrm{N}$ additions modified to yield an N:P ratio of 16:1 (Guillard 1975). Trace metals were added according to the L1 media recipe (Guillard \& Hargraves 1993).

One set of Scrippsiella trochoidea cultures were established for the grazer exposure experiment and one set for the grazing experiment. For each experiment, the cultures were grown in duplicate in 21 glass culture flasks at $16^{\circ} \mathrm{C}$ and a photon flux density of $100 \mu \mathrm{mol}$ photons $\mathrm{m}^{-2} \mathrm{~s}^{-1}$, supplied at a light:dark cycle of 16:8 h. We chose this light:dark cycle because $S$. trochoidea occurs in Swedish waters during May to June when the day and night lengths match this cycle. Growth of these cultures was followed by daily measurements of chlorophyll a with a Turner Designs 10AU fluorometer. S. trochoidea cultures were harvested in mid-exponential phase for both the grazer exposure experiment and the grazing experiment. The Rhodomonas salina culture was grown in a $10 \mathrm{l}$ culture flask at the same temperature and light conditions as the $S$. trochoidea cultures, but was aerated with sterile air (Sartorius Minisart ${ }^{\circledR}$ filter, $0.2 \mu \mathrm{m}$ ) to facilitate mixing. This $R$. salina culture had been used as prey for copepod cultures prior to the experiments presented here, and had grown as a semi-continuous culture for 60 or $150 \mathrm{~d}$ depending on the experiment in which the culture was used. On a daily basis, $10 \%$ of the culture volume was removed, fed to copepod cultures, and replaced with $\mathrm{F} / 2$ medium.

All experiments were conducted with adult females of Acartia tonsa, which originated from cultures held at the Sven Lovén Centre for Marine Sciences, Gothenburg University. Water (10 l) from an Acartia culture was transported in a plastic container to our laboratory within $24 \mathrm{~h}$. The copepods were then put in a $100 \mathrm{l}$ glass aquarium with air bubbling at $16^{\circ} \mathrm{C}$ and under dim light. These copepods were subsequently fed daily with Rhodomonas salina at saturating concentrations. Eggs were collected after approximately $14 \mathrm{~d}$ and stored in a refrigerator at 2 to $3^{\circ} \mathrm{C}$, until they were used to establish a new generation of $A$. tonsa, with adult females of known age. Eggs hatched within $48 \mathrm{~h}$ in filtered seawater at $16^{\circ} \mathrm{C}$, the nauplii were then put in a 1001 aquarium, again fed on a daily diet of $R$. salina in dim light. After about 20 d, most nauplii had developed to adult individuals and the experiments could be started. A new generation of $A$. tonsa was established in the manner described above for the grazing experiment, which started approximately 3 mo later than the grazer exposure experiment.

Grazer exposure experiment. The experimental setup included 2 grazer treatments - low density treatment, LD, 6 Acartia tonsa $\mathrm{l}^{-1}$, and high density treatment, HD, 30 A. tonsa $1^{-1}$-and one grazer-free control, C, in both high light $\left(100 \mu \mathrm{mol}\right.$ photons $\mathrm{m}^{-2} \mathrm{~s}^{-1}$, 16:8 h light:dark cycle) and low light ( 5 mol photons $\mathrm{m}^{-2} \mathrm{~s}^{-1}, 16: 8 \mathrm{~h}$ light:dark cycle) conditions. Each treatment was replicated 3 times, i.e. a total of 18 glass culture flasks (Schott Duran, 0.5 l) were used (Fig. 1). The densities of $A$. tonsa used here, i.e. 6 to $30 \mathrm{l}^{-1}$, are within the range for this species in situ (Cervetto et al. 1993, Purcell et al. 1994).

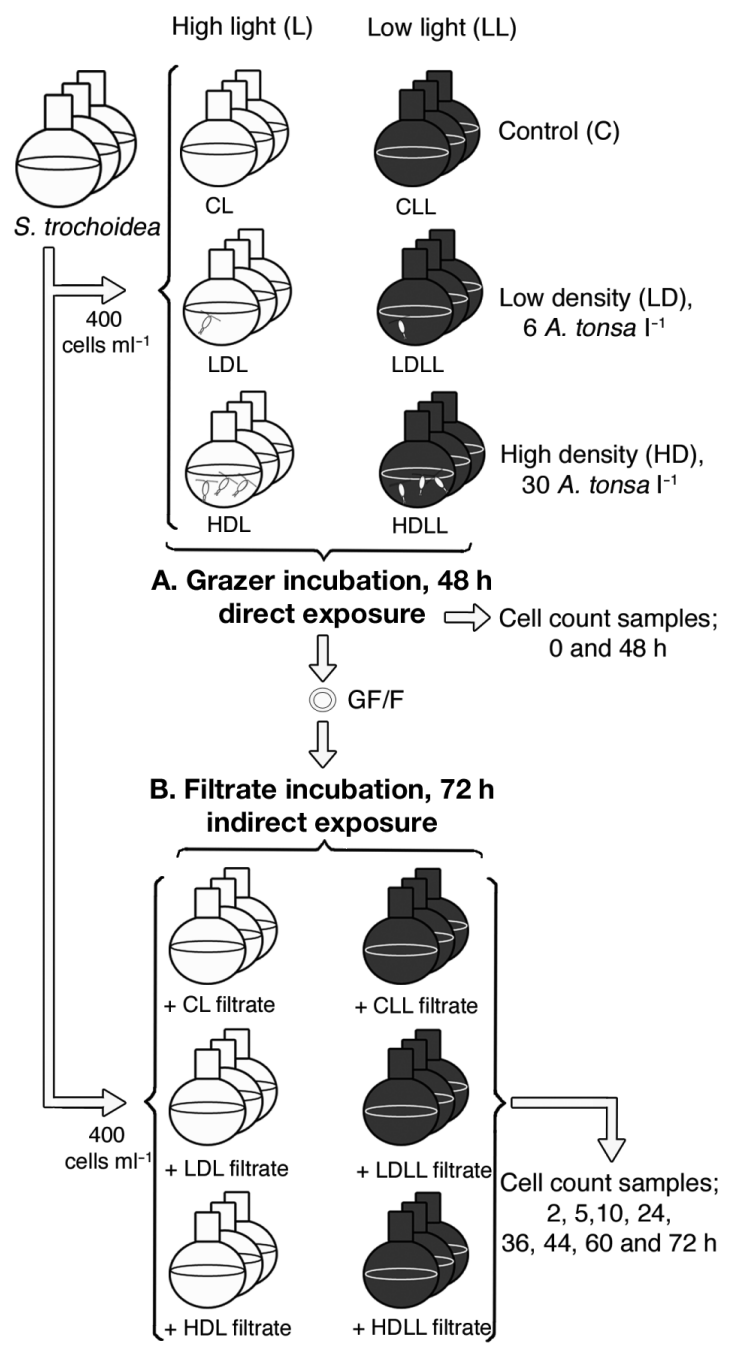

Fig. 1. Experimental design used to investigate effects of (A) direct and (B) indirect exposure to increasing densities of Acartia tonsa in high light $\left(100 \mu \mathrm{mol}\right.$ photons $\left.\mathrm{m}^{-2} \mathrm{~s}^{-1}\right)$ and low light ( $5 \mu \mathrm{mol}$ photons $\mathrm{m}^{-2} \mathrm{~s}^{-1}$ ) conditions on cyst formation by Scrippsiella trochoidea 
Adult and healthy Acartia tonsa females were selected from the copepod culture under a stereomicroscope (Nikon SMZ-2T), and placed in $1000 \mathrm{ml}$ filtered seawater for $12 \mathrm{~h}$ prior to the initiation of the experiment to facilitate gut clearance. Scrippsiella trochoidea cultures were harvested in mid-exponential phase and inoculated into each flask at a target concentration of 400 cells ml ${ }^{-1}$, corresponding to a carbon (C) concentration of $560 \mathrm{\mu g} \mathrm{C}^{-1}$ (1357 $\mathrm{pg} \mathrm{C}$ cell $^{-1}$, based on previous measurements of particulate organic carbon, $\mathrm{POC}$ ). We chose this concentration because S. trochoidea cell concentrations lie around this value during the build-up of $S$. trochoidea blooms (Wang et al. 2007). At the corresponding carbon concentration, $560 \mu \mathrm{g} \mathrm{C} 1^{-1}, A$. tonsa ingestion rates are high but not completely saturated (Kiørboe et al. 1985). For treatments LD, 3 adult $A$. tonsa females were added to a total of 6 flasks, i.e. 3 flasks for treatment LD in high light conditions (LDL) and 3 flasks for treatment LD in low light conditions (LDLL). In the same manner, for treatments HD, 15 adult $A$. tonsa females were added to 6 flasks, 3 flasks for treatment HD in high light conditions (HDL) and 3 flasks for treatment HD in low light conditions (HDLL). A total of 6 flasks were left without grazers and used as controls; 3 flasks in high light (CL) and 3 flasks in low light conditions (CLL) (Fig. 1A). To facilitate mixing, all flasks were gently stirred by hand 5 times a day. Grazer and control incubations lasted for $48 \mathrm{~h}$ in order to allow the copepods time to adjust to the food. Samples for cell enumeration were taken initially and at the end of this incubation.

After $48 \mathrm{~h}$ the contents of each flask were filtered through GF/F glass fiber filters and the filtrates were used to inoculate new Scrippsiella trochoidea at a target concentration of 400 cells ml $^{-1}$ (Fig. 1B). This procedure allowed us to assess the indirect (i.e. infochemically driven) effect of increasing grazer density on $S$. trochoidea cyst formation in high light and in low light conditions. Filtrate incubation lasted for a total of $72 \mathrm{~h}$, during which time samples for cell counts were taken from each flask in a time series as follows: $2,5,10,24$, $36,44,60$ and $72 \mathrm{~h}$. Previous experiments on the induction of temporary cysts in dinoflagellates in response to parasite-derived chemical signals have shown that such responses could occur quickly and subside within a few hours (Toth et al. 2004). This was the main reason why we sampled for cell counts in time intervals as short as 2 to $10 \mathrm{~h}$, in addition to the longer intervals of 24 to $72 \mathrm{~h}$.

Grazing experiment. In order to estimate the food quality of Scrippsiella trochoidea vegetative cells and temporary cysts, Acartia tonsa females were incubated with 3 different food suspensions as follows: (1) S. trochoidea dominated by vegetative cells $(78 \%$ vegetative cells, $22 \%$ temporary cysts, hereafter referred to as the vegetative cell treatment), (2) a 50:50\% mixture of vegetative cells and temporary cysts (hereafter referred to as the mixture treatment), and (3) S. trochoidea dominated by temporary cysts (83\% temporary cysts, $17 \%$ vegetative cells, hereafter referred to as the temporary cyst treatment). Temporary cysts needed for the mixture treatment and the temporary cyst treatment were induced by placing duplicate culture flasks $\left(\begin{array}{ll}1 & \mathrm{l}\end{array}\right)$ with exponentially growing $S$. trochoidea ( $\mathrm{F} / 2$ medium) in the dark for $72 \mathrm{~h}$ prior to the start of the experiment, after which $83 \%$ of the total number of vegetative cells and cysts consisted of temporary cysts. All food suspensions were prepared by diluting the vegetative cell cultures and the temporary cyst cultures with appropriate amounts of autoclaved filtered seawater (FSW) to obtain a saturating food concentration of $800 \mathrm{ug} \mathrm{Cl}^{-1}$. We had no measurement of the carbon content of temporary cysts and therefore initially aimed at setting the concentration of vegetative cells and temporary cysts in the mixture treatment to be of the same volume, so that the clearance rate of A. tonsa would not be affected. The volume of vegetative cells $\left(7950 \pm 1649 \mu^{3}\right.$, mean $\left.\pm \mathrm{SD}, \mathrm{n}=10\right)$ and temporary cysts $\left(6559 \pm 1073 \mu^{3}{ }^{3}, \mathrm{n}=10\right)$ were measured, and no significant difference was found (MannWhitney $U$ test, $\mathrm{p}=0.087$ ). Therefore, vegetative cells and temporary cysts were assumed to have the same carbon content and set at the same concentration $\left(295\right.$ cells/cysts $\left.\mathrm{ml}^{-1}\right)$ in the mixture treatment. Table 1 shows the target densities and real densities obtained in each treatment.

The grazing experiment lasted for $2 \mathrm{~d}$ and consisted of 2 subsequent $24 \mathrm{~h}$ incubations at $16^{\circ} \mathrm{C}$ and a light intensity of $100 \mu \mathrm{mol}$ photons $\mathrm{m}^{-2} \mathrm{~s}^{-1}$ (light:dark cycle, 16:8 h). After each $24 \mathrm{~h}$ incubation period production of eggs and faecal pellets was assessed, while ingestion was only determined during the second $24 \mathrm{~h}$ incubation. Acartia tonsa females were chosen from the copepod culture in the same manner as described above for the grazer exposure experiment and acclimatized to the experimental diets for $24 \mathrm{~h}$, before initiating the grazing experiment. The experimental containers were $250 \mathrm{ml}$ Erhlenmeyer flasks, which were

Table 1. Target concentrations of prey (Scrippsiella trochoidea) cells as well as real initial cell concentrations (cells $\mathrm{ml}^{-1}$ ) in the vegetative cell treatment, the mixture treatment, and the temporary cysts treatment (mean $\pm \mathrm{SD}, \mathrm{n}=3$ )

\begin{tabular}{|lcccc|}
\hline \multirow{2}{*}{ Treatment } & \multicolumn{2}{l}{ Vegetative cells } & \multicolumn{2}{c|}{ Temporary cysts } \\
& Target & Real & Target & Real \\
\hline Vegetative cell & 462 & $440 \pm 43.6$ & 128 & $126 \pm 40.8$ \\
Mixture & 295 & $303 \pm 15.3$ & 295 & $290 \pm 30.1$ \\
Temporary cyst & 100 & $116 \pm 24.0$ & 490 & $551 \pm 36.5$ \\
& & & & \\
\hline
\end{tabular}


filled to a total volume of $100 \mathrm{ml}$ with the different food suspensions detailed above. Three adult A. tonsa females were added to each flask, and the result was that the total copepod carbon corresponded to about $19 \%$ of the algal carbon in the experimental flasks. Each food suspension treatment was replicated 3 times, i.e. we used a total of 9 flasks. To calculate ingestion we also included triplicate control flasks, without addition of copepods, of the 3 different food suspensions during the second incubation, i.e. an additional 9 flasks were used during the second $24 \mathrm{~h}$ period. All experimental flasks were put on shaking tables to keep cells and cysts in suspension.

To calculate ingestion rates, we sampled for cell counts from all flasks initially on Day 1 and at the end of Day 2. After each $24 \mathrm{~h}$ incubation, the content of each flask was first filtered through a $200 \mu \mathrm{m}$ net to collect copepods. The condition of the copepods was checked using a stereomicroscope before they were gently transferred to a new flask with a freshly prepared food suspension, in accordance with the procedures detailed above. The remaining filtrate was filtered onto a $40 \mu \mathrm{m}$ mesh size nylon net in order to collect eggs and faecal pellets. Eggs and faecal pellets were rinsed with FSW into $50 \mathrm{ml}$ centrifuge tubes and preserved with acidic Lugols solution (4\% final concentration).

Analytical procedures. All samples for cell counts were preserved in a $0.5 \%$ final concentration of glutaraldehyde and stored in darkness and at $4{ }^{\circ} \mathrm{C}$ before enumeration. Depending on varying concentrations of cysts and vegetative cells between samples, 2.65 or $10 \mathrm{ml}$ Utermöhl chambers were used to count vegetative cells and cysts with an inverted microscope (Olympus CKX41) at 200× magnification. At least 100, but in $70 \%$ of all samples more than 300 cells (11\% error), were counted for each cell type, except for the low light treatments towards the end of the grazer exposure experiment where the very low concentrations of the vegetative cells prevented us from counting more than 50 vegetative cells (28\% error).

Production of eggs and faecal pellets from the various diets were assessed with the inverted microscope at $40 \times$ magnification using graded petri dishes. Faecal pellet volumes were estimated for all replicates in each treatment by measuring the length and width of 30 pellets per replicate. Previous measurements of POC and particulate organic nitrogen (PON) in our laboratory revealed an $\mathrm{N}$ :C ratio of approximately 0.2 for Scrippsiella trochoidea, a food N:C ratio at which Acartia tonsa contains $5.2 \mu \mathrm{g} \mathrm{C}$ ind. ${ }^{-1}$ (Miller \& Roman 2008). This carbon content of $A$. tonsa was used to estimate weight-specific ingestion rate and egg production.

For each treatment in the grazing experiment, we calculated the total weight-specific ingestion, i.e. ingestion on vegetative cells and temporary cysts summed, as well as weight-specific ingestion on vegetative cells and temporary cysts separately. All ingestion rates were calculated according to Frost (1972).

The carbon content of the eggs was estimated from an average egg diameter of $83.7 \pm 2.5 \mu \mathrm{m}(\mathrm{n}=10)$ and a carbon content of $0.14 \times 10^{-6} \mu \mathrm{g} \mathrm{C} \mu \mathrm{m}^{-3}$ (Huntley \& Lopez 1992). Gross growth efficiency (GGE, \% d $\mathrm{d}^{-1}$ ) of Acartia tonsa was determined by dividing the weightspecific egg production rate with the total weightspecific ingestion.

Samples for inorganic nutrients $\left(\mathrm{NO}_{3}{ }^{-}, \mathrm{PO}_{4}{ }^{3-}\right.$, and $\mathrm{NH}_{4}{ }^{+}$) and $\mathrm{pH}$ were collected from each experimental flask after filtrate incubations in the grazer exposure experiment. $\mathrm{NO}_{3}{ }^{-}$and $\mathrm{PO}_{4}{ }^{3-}$ samples were filtered through Whatman GF/C glass fiber filters and frozen until analysed photometrically (Hach Lange DR5000); samples for $\mathrm{NH}_{4}{ }^{+}$were analysed immediately after collection, according to Valderrama (1995). Samples for $\mathrm{pH}$ were directly measured with a calibrated WTW inoLab $\mathrm{pH}$ meter.

Statistical analyses. All percentage data (i.e. percentage of cells as cysts and GGE) were arcsine transformed before statistical analysis. In the direct exposure experiment, data on percentages of cells as cysts were analysed for effects of increasing Acartia tonsa densities and altered light conditions on cyst formation of Scrippsiella trochoidea after $48 \mathrm{~h}$ with a 2-way ANOVA. In the indirect exposure experiment, a 3-way repeated measures ANOVA was used to examine how $S$. trochoidea cyst formation changed through the experiment. Mauchly's test was performed to test the assumption of sphericity, while Levene's tests were used to check all data for homogenous variances and Shapiro-Wilks' tests were used to check for normal distributions. In the indirect exposure experiment, data from the time points $5 \mathrm{~h}$ and $60 \mathrm{~h}$ had to be excluded from the statistical analyses as they did not fulfil the assumption of homogenous variances. Data from analyses of inorganic nutrients and $\mathrm{pH}$ were analyzed with a 1-way ANOVA. In the grazing experiment, 1way ANOVA was used to examine differences in concentrations of vegetative cells and temporary cysts between control and grazing flasks at the end of incubation. Only if differences were statistically significant were ingestion rates calculated. Ingestion rates were tested against zero (insignificant ingestion), again using 1-way ANOVAs. The same test was also used to test whether the 3 different diets offered to A. tonsa resulted in significantly different ingestion rates, as well as in different faecal and egg productions. If the ANOVAs demonstrated statistically significant differences, they were followed by Tukey's post hoc tests. All statistical analyses were performed with SPSS 13.0. All data are presented as mean \pm SD. 


\section{RESULTS}

\section{Grazer exposure experiment}

\section{Direct exposure}

We observed no effect of increasing Acartia tonsa densities on percentages of cells as temporary cysts in either high light or low light conditions (Fig. 2A). There was, however, an effect of low light conditions. Grazer treatments and the control in the low light condition (CLL, LDLL and HDLL) all showed increasing percentages of cells as temporary cysts; from an initial average of $21.41 \pm 1.43 \%$ to an average of 52.56 $\pm 2.20 \%$ after $48 \mathrm{~h}$ (Fig. 2A). At the same time, the grazer treatments and the control exposed to higher light intensities (CL, LDL and HDL) showed no such increase in temporary cyst densities as the average percentage of temporary cysts was initially $20.89 \pm$ $1.39 \%$, compared to $19.40 \pm 0.85 \%$ after $48 \mathrm{~h}$ (Fig. 2A). Correspondingly, a 2-way ANOVA revealed a significant effect of light condition alone $\left(F_{1,12}=\right.$ 195.37, p < 0.001), while no significant effect was detected concerning grazer density alone $\left(F_{2,12}=0.38\right.$, $\mathrm{p}=0.692$ ). Similarly, no significant difference in terms of temporary cyst formation was found between the interaction of light condition and grazer density $\left(F_{2,12}\right.$ $=0.25, \mathrm{p}=0.782$ ). No hypnocysts were observed in any treatment of the direct exposure experiment in high light or low light conditions.
Indirect exposure

All grazer treatments and controls in both high light and low light conditions showed similar percentages of cells as temporary cysts during the first $10 \mathrm{~h}$ of the experiment, with an average of $21.26 \pm 2.06 \%$. After $10 \mathrm{~h}$, the proportion of temporary cysts in controls and grazer treatments followed the same trend as for the direct exposure experiment. In fact, after $72 \mathrm{~h}$ of incubation with the grazer filtrates and in their controls, the percentages of cells as temporary cysts in the low light condition increased to an average of $82.47 \pm 2.14 \%$ (CLL, LDLL and HDLL), whereas those in light (CL, LDL and HDL) remained at lower levels (19.49 \pm $1.62 \%$ ) (Fig. 2B). Three-way ANOVA revealed a significant effect of light condition over time $\left(F_{1,12}=\right.$ 1578.71, p < 0.001), while no significant effects of increasing Acartia tonsa density filtrates could be discerned $\left(F_{2,12}=0.06, \mathrm{p}=0.946\right)$. Moreover, there was no interaction effect of light condition and grazer density $\left(F_{2,12}=1.96, \mathrm{p}=0.184\right)$. No hypnocysts were detected in any treatment in high light or low light conditions.

\section{Inorganic nutrients and $\mathrm{pH}$}

After $72 \mathrm{~h}$ of filtrate incubation, nitrate and phosphate occurred at high concentrations in all controls and grazer treatments of the grazer exposure experiment. $\mathrm{NO}_{3}{ }^{-}$concentrations varied from $452.67 \pm$
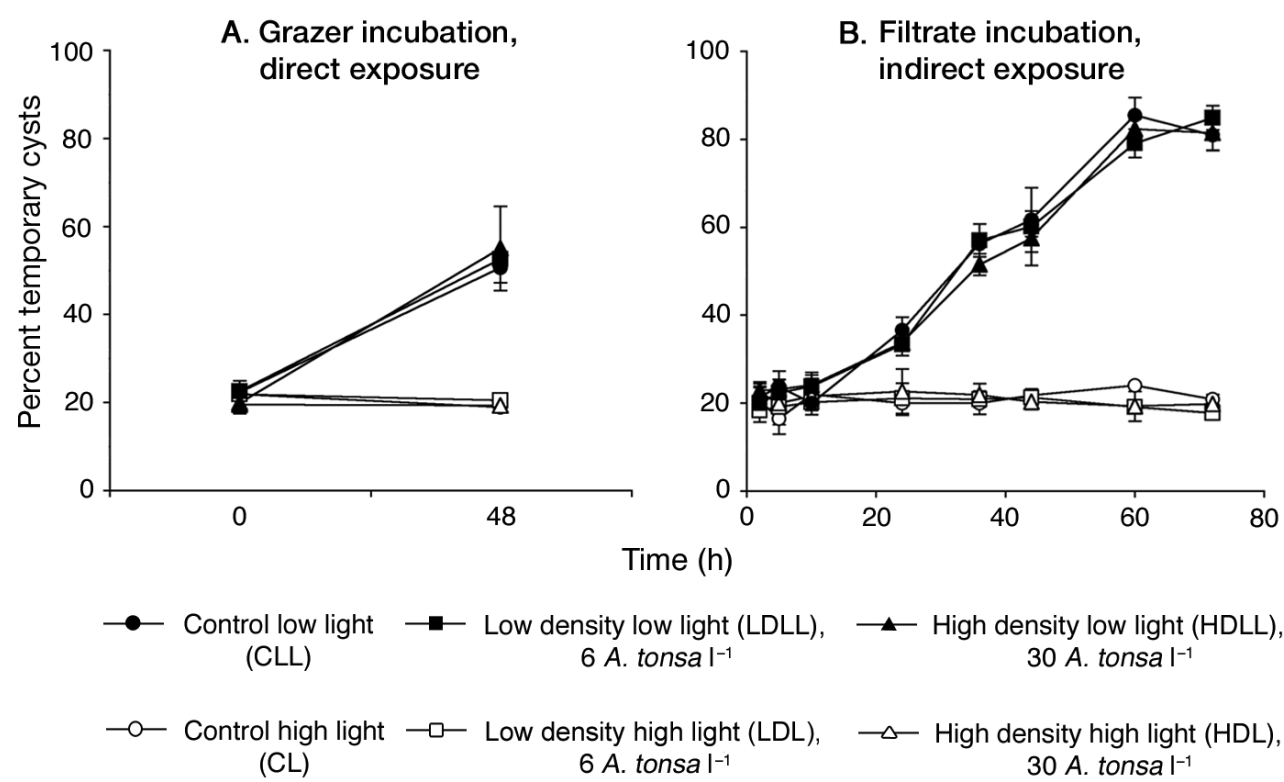

Fig. 2. Scrippsiella trochoidea and Acartia tonsa. Percentages of $S$. trochoidea cells as temporary cysts in the 2 tested light conditions, high light $\left(100 \mu \mathrm{mol}\right.$ photons $\left.\mathrm{m}^{-2} \mathrm{~s}^{-1}\right)$ and low light $\left(5 \mu \mathrm{mol}\right.$ photons $\left.\mathrm{m}^{-2} \mathrm{~s}^{-1}\right)$ after (A) direct exposure and (B) indirect

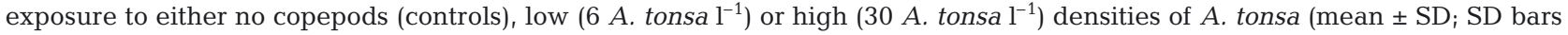
sometimes hidden behind symbol, $\mathrm{n}=3$ ) 
$33.12 \mu \mathrm{mol} \mathrm{l}^{-1}$ in HDL to $533.68 \pm 38.41 \mu \mathrm{mol} \mathrm{l}^{-1}$ in CLL. $\mathrm{PO}_{4}{ }^{3-}$ concentrations ranged from $25.10 \pm 1.45 \mu \mathrm{mol} \mathrm{l}^{-1}$ in HDL to $30.63 \pm 1.57 \mu \mathrm{mol} \mathrm{l}^{-1}$ in CLL (Table 2). No significant differences in either $\mathrm{NO}_{3}{ }^{-}$or $\mathrm{PO}_{4}{ }^{3-}$ concentrations were found between the control and the 2 grazer treatments within each tested light condition $(p>0.05)$. However, the control and the grazer treatments in the low light condition (CLL, LDLL and HDLL) all displayed significantly higher concentrations of $\mathrm{PO}_{4}{ }^{3-}$ compared to those in the high light $(\mathrm{CL}$, LDL and HDL) $\left(F_{5,12}=15.91, \mathrm{p}<0.050\right) . \mathrm{NO}_{3}{ }^{-}$concentrations were also higher in the control and in the grazer treatments exposed to lower light compared to the control and the grazer treatments in higher light, although the increase was not statistically significant $\left(F_{5,12}=2.34, \mathrm{p}=0.106\right)$ (Table 2$)$.

At the end of the experiment, $\mathrm{NH}_{4}{ }^{+}$concentrations were low and varied from $0.20 \pm 0.05 \mu \mathrm{mol}^{-1}$ in CLL to $0.46 \pm 0.04 \mu \mathrm{mol} \mathrm{l}^{-1}$ in HDLL (Table 2). The low- and the high-density grazer filtrate treatments (LDL, LDLL, HDL and HDLL) had significantly higher concentrations of $\mathrm{NH}_{4}{ }^{+}$compared to the controls (CL and CLL). This was evident in both the high light $\left(F_{5,12}=17.82\right.$, $\mathrm{p}=0.005$ for LDL and $\mathrm{p}=0.001$ for HDL) and the low light condition $(p=0.002$ for LDLL and $p=0.014$ for HDLL) (Table 2).

Values of $\mathrm{pH}$ showed little variation between treatments, varying from $8.64 \pm 0.11$ in LDLL to $8.69 \pm 0.05$ in HDL (Table 2). No significant differences in $\mathrm{pH}$ could be detected between any grazer treatment and control in either light or low light conditions $\left(F_{5,12}=\right.$ $0.21, \mathrm{p}=0.951$ ) (Table 2).

\section{Grazing experiment}

Ingestion

The total weight-specific ingestion rate, i.e. ingestion on vegetative cells and temporary cysts combined, of Acartia tonsa decreased with increasing concentrations of Scrippsiella trochoidea temporary cysts

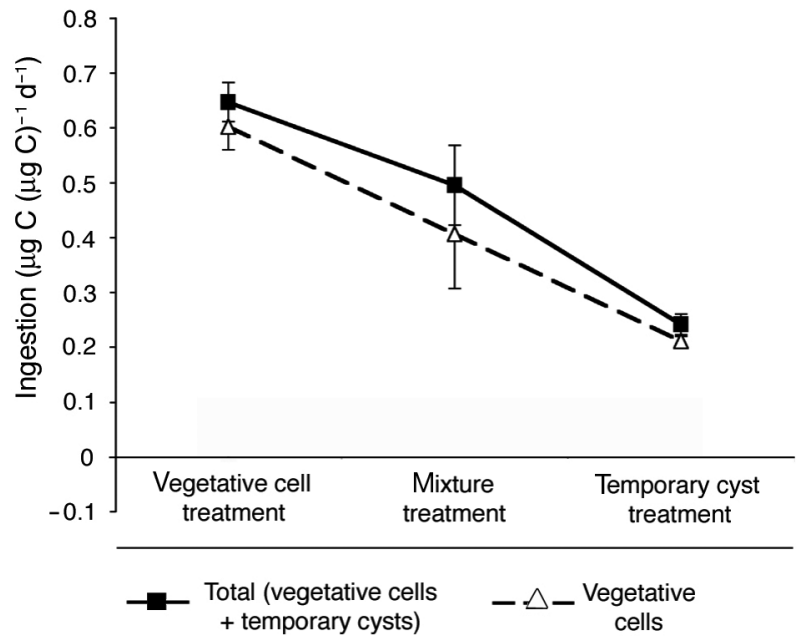

Fig. 3. Acartia tonsa feeding on Scrippsiella trochoidea. Weight-specific ingestion by $A$. tonsa in the vegetative cell treatment, the mixture treatment, and in the temporary cyst treatment. For each treatment, the total ingestion of both $S$. trochoidea vegetative cells and temporary cysts, as well as the separate ingestion of vegetative cells are shown (mean \pm $\mathrm{SD}, \mathrm{n}=3$ )

(Fig. 3). The observed total ingestion was $0.64 \pm$

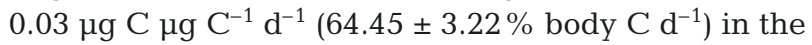
vegetative cell treatment, which decreased significantly to $0.50 \pm 0.07 \mu \mathrm{g} \mathrm{C} \mu \mathrm{g} \mathrm{C}^{-1} \mathrm{~d}^{-1}(49.39 \pm 7.72 \%$ body $\left.\mathrm{C} \mathrm{d}^{-1}\right)$ in the mixture treatment $\left(F_{2,6}=55.01, \mathrm{p}=\right.$ $0.019)$, and to $0.24 \pm 0.02 \mu \mathrm{g} \mathrm{C} \mu \mathrm{g} \mathrm{C}^{-1} \mathrm{~d}^{-1}(49.39 \pm$ $7.72 \%$ body $\left.\mathrm{C} \mathrm{d}^{-1}\right)(\mathrm{p}<0.001)$ in the temporary cyst treatment. The ingestion on vegetative cells of $S$. trochoidea also decreased as the percentage of temporary cysts increased-from $0.60 \pm 0.04 \mu \mathrm{g} \mathrm{C} \mu \mathrm{g} \mathrm{C}^{-1} \mathrm{~d}^{-1}$ $\left(59.13 \pm 2.87 \%\right.$ body $\left.\mathrm{C} \mathrm{d}^{-1}\right)$ in the vegetative cell treatment to $0.41 \pm 0.10 \mu \mathrm{g} \mathrm{C} \mu \mathrm{g} \mathrm{C} \mathrm{C}^{-1} \mathrm{~d}^{-1}(40.50 \pm 9.70 \%$ body $\left.\mathrm{C} \mathrm{d}^{-1}\right)\left(F_{2,6}=29.46, \mathrm{p}=0.020\right)$ in the mixture treat-

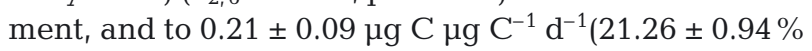
body $\left.\mathrm{C} \mathrm{d}^{-1}\right)(\mathrm{p}=0.001)$ in the temporary cyst treatment (Fig. 3). Ingestion rates on temporary cysts were not computed since their densities did not differ significantly at the end of the incubation.

Table 2. Inorganic nutrient concentrations $\left(\mu \mathrm{mol} \mathrm{l}^{-1}\right.$ ) and $\mathrm{pH}$ values in the controls and grazer treatments of the 2 tested light conditions (high light and low light) after $3 \mathrm{~d}$ of filtrate incubation (indirect exposure experiment). Asterisks indicate significant differences from the control within each tested light condition; ${ }^{*} p<0.05,{ }^{* *} p<0.01,{ }^{* * *} p<0.001 . F$ and $p$-values are also given $($ mean $\pm \mathrm{SD}, \mathrm{n}=3$ ).

\begin{tabular}{|c|c|c|c|c|c|c|c|c|}
\hline & \multicolumn{3}{|c|}{ High light $\left(100 \mu \mathrm{mol}\right.$ photons $\left.\mathrm{m}^{-2} \mathrm{~s}^{-1}\right)$} & \multicolumn{3}{|c|}{ Low light $\left(5 \mu \mathrm{mol}\right.$ photons $\left.\mathrm{m}^{-2} \mathrm{~s}^{-1}\right)$} & \multirow[t]{2}{*}{$F_{5,12}$} & \multirow[t]{2}{*}{$\mathrm{p}$} \\
\hline & $\begin{array}{l}\text { Control, } \\
\text { CL }\end{array}$ & $\begin{array}{l}\text { Low density, } \\
\text { LDL }\end{array}$ & $\begin{array}{l}\text { High density, } \\
\text { HDL }\end{array}$ & $\begin{array}{l}\text { Control, } \\
\text { CLL }\end{array}$ & $\begin{array}{l}\text { Low density, } \\
\text { LDLL }\end{array}$ & $\begin{array}{l}\text { High density, } \\
\text { HDLL }\end{array}$ & & \\
\hline $\mathrm{NO}_{3}^{-}$ & $470.99 \pm 36.68$ & $467.23 \pm 43.76$ & $452.67 \pm 33.12$ & $533.68 \pm 38.41$ & $528.28 \pm 37.51$ & $497.75 \pm 38.79$ & 2.34 & 0.106 \\
\hline $\mathrm{PO}_{4}^{3-}$ & $26.22 \pm 0.24$ & $25.47 \pm 1.39$ & $25.10 \pm 1.45$ & $30.63 \pm 1.57$ & $29.99 \pm 0.70$ & $30.04 \pm 0.66$ & 15.9 & 0.000 \\
\hline $\mathrm{NH}_{4}^{+}$ & $0.20 \pm 0.05$ & $0.38 \pm 0.06^{* *}$ & $0.41 \pm 0.06^{* * *}$ & $0.20 \pm 0.02$ & $0.34 \pm 0.01^{* *}$ & $0.46 \pm 0.04^{*}$ & 17.8 & 0.000 \\
\hline $\mathrm{pH}$ & $8.67 \pm 0.03$ & $8.66 \pm 0.08$ & $8.69 \pm 0.05$ & $8.66 \pm 0.07$ & $8.64 \pm 0.11$ & $8.65 \pm 0.04$ & 0.21 & 0.951 \\
\hline
\end{tabular}


Egestion

Acartia tonsa faecal pellet production rates followed the same trend as ingestion, i.e. an increasing percentage of Scrippsiella trochoidea temporary cysts caused a decreased production of faecal pellets. This was apparent on both Day 1 and Day 2 of the experiment (Fig. 4). On Day 1, a significantly lower faecal pellet production rate, $13.89 \pm 3.00$ pellets female $\mathrm{e}^{-1} \mathrm{~d}^{-1}$, was observed in the temporary cyst treatment compared with the vegetative cell treatment, which had a rate of $29.67 \pm 3.21$ pellets female $\mathrm{d}^{-1} \mathrm{~d}^{-1}\left(F_{2,6}=22.51, \mathrm{p}=0.002\right)$, whereas in the mixture treatment the rate was $28.22 \pm 3.24$ pellets female $^{-1} \mathrm{~d}^{-1}(\mathrm{p}=0.004)$. The same pattern was observed on Day 2 of the experiment; while the pellet production rate in the vegetative cell treatment was 31.78 \pm 5.18 pellets female ${ }^{-1} \mathrm{~d}^{-1}$, the temporary cyst treatment had a significantly lower pellet production rate of 14.00 \pm 1.53 pellets female ${ }^{-1} \mathrm{~d}^{-1}\left(F_{2,6}=14.93, \mathrm{p}=0.005\right)$. The pellet production rate in the temporary cyst treatment was also significantly lower than that observed in the mixture treatment which had a pellet production rate of $28.11 \pm 5.01$ pellets female ${ }^{-1} \mathrm{~d}^{-1}(\mathrm{p}=0.015)$.

Average faecal pellet sizes $\left(\mathrm{mm}^{3} \times 10^{-4}\right)$ varied from $1.16 \pm 0.01$ to $1.23 \pm 0.05$ and no significant differences could be detected on Day $1\left(F_{2,6}=1.32, \mathrm{p}=0.330\right)$ or on Day $2\left(F_{2,6}=1.21, \mathrm{p}=0.360\right)$.

\section{Reproduction}

In accordance with ingestion rates and faecal pellet production rates, average egg production rates decreased with increasing concentrations of temporary

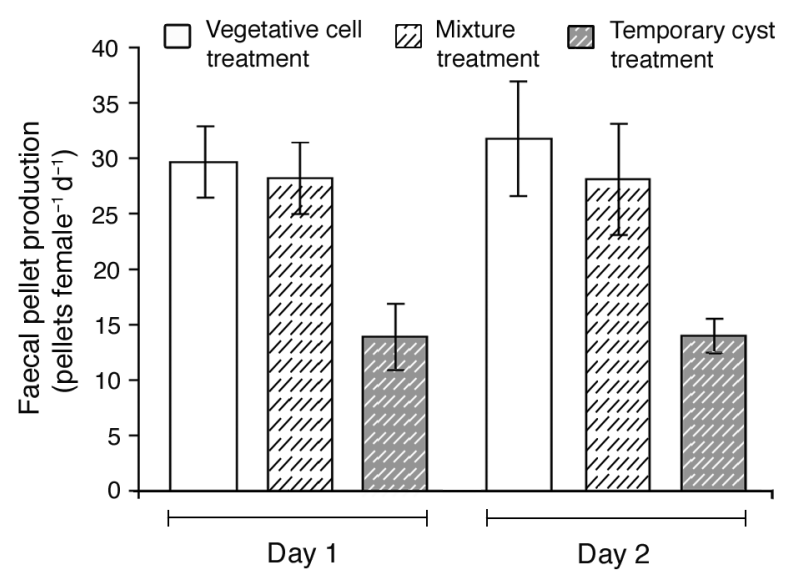

Fig. 4. Acartia tonsa feeding on Scrippsiella trochoidea. Faecal pellet production of $A$. tonsa, on Day 1 and Day 2 of the grazing experiment, feeding on $S$. trochoidea vegetative cells (vegetative cell treatment), a 50:50\% mixture of $S$. trochoidea vegetative cells and temporary cysts (mixture treatment), and temporary cysts (temporary cyst treatment) (mean $\pm \mathrm{SD}, \mathrm{n}=3$ ) cysts on both Day 1 and Day 2 (Fig. 5). On Day 1, the lowest egg production rate, $4.11 \pm 0.84$ eggs female $^{-1}$ $\mathrm{d}^{-1}$, occurred in the temporary cyst treatment. Egg production rates increased significantly to $9.67 \pm 2.08$ eggs female $\mathrm{e}^{-1} \mathrm{~d}^{-1}$ in the mixture treatment $\left(F_{2,6}=14.9, \mathrm{p}=\right.$ 0.030 ) and to $12.67 \pm 2.52$ eggs female ${ }^{-1} \mathrm{~d}^{-1}$ in the vegetative cell treatment $(p=0.004)$. A similar trend occurred on Day 2, with an egg production rate of 4.88 \pm 1.02 eggs female ${ }^{-1} \mathrm{~d}^{-1}$ in the temporary cyst treatment, which increased significantly to $10.33 \pm 2.08$ eggs female $\mathrm{e}^{-1} \mathrm{~d}^{-1}$ in the mixture treatment $\left(F_{2,6}=21.4\right.$, $\mathrm{p}=0.014)$ and to $13.33 \pm 1.53$ eggs female ${ }^{-1} \mathrm{~d}^{-1}$ in the vegetative cell treatment $(p=0.002)$.

The gross growth efficiency (GGE) varied from 16.93 \pm 4.83 to $17.11 \pm 1.10 \%$ (Fig. 5). There were no significant differences in GGE between treatments $\left(F_{2,6}=\right.$ 0.011, $\mathrm{p}=0.989$ ).

\section{DISCUSSION}

\section{Grazer exposure experiment}

Effects of decreased light

Our results show that the factor that had induced Scrippsiella trochoidea temporary cyst formation was the low light condition. Temporary cyst formation was high under low light in both the direct and indirect exposure experiments (Fig. 2). Similarly, Rintala et al. (2007) have found that the dark survival strategy of the closely related $S$. hangoei includes reducing respiration rates to very low levels by increasing temporary cyst formation in response to darkness.

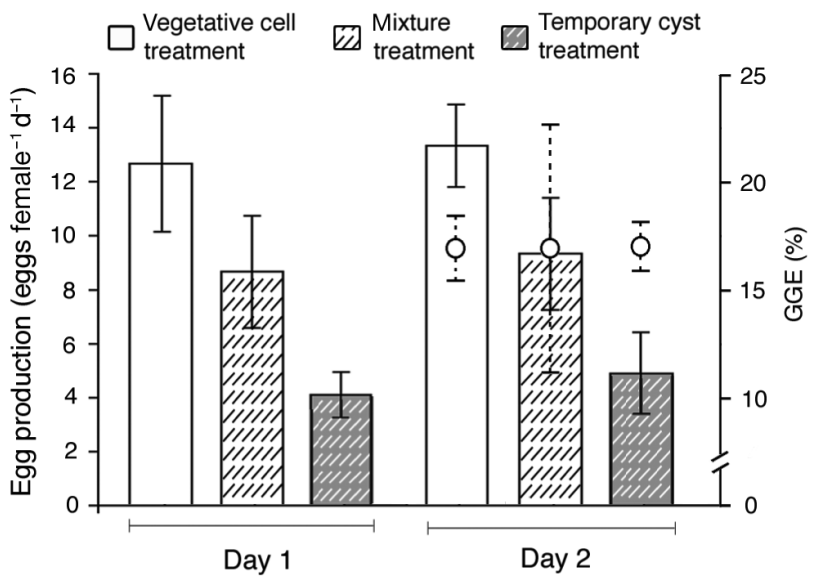

Fig. 5. Acartia tonsa feeding on Scrippsiella trochoidea. Egg production of $A$. tonsa, on Day 1 and Day 2 of the grazing experiment, in the vegetative cell treatment, the mixture treatment and in the temporary cyst treatment. On Day 2, gross growth efficiency (GGE,\%) (white circles) in the different treatments is also presented (mean $\pm \mathrm{SD}, \mathrm{n}=3$ ) 
As nitrate and phosphate concentrations were high and $\mathrm{pH}$ did not differ significantly between any treatments in either high light or low light conditions, we can assume that the increased formation of temporary cysts observed in response to decreased light intensity has nothing to do with either $\mathrm{N}$ or $\mathrm{P}$ deficiency or $\mathrm{pH}$ conditions. Although concentrations of ammonium

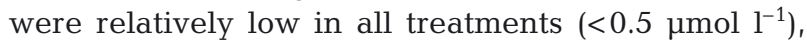
they were significantly higher in all treatments where grazers were added, i.e. in treatments LDL, HDL, LDLL, and HDLL, compared to the controls, CL and CLL. This reflected ammonium excretion of copepods (Kiørboe et al. 1985). However, the higher levels of ammonium found in our grazer treatments had no effect on the formation of cysts, as the density of temporary cysts did not vary in the presence of Acartia tonsa and no hypnocysts were found in any of these treatments.

In the present study, high percentages of temporary cysts were observed in response to low light conditions, i.e. 50 to $80 \%$. It is not common for all cells within a given population to form cysts in response to adverse conditions. Moreover, the proportion of cells forming cysts can vary a great deal between natural population surveys and laboratory experiments. In laboratory conditions, Rintala et al. (2007) reported that $50 \%$ of the Scrippsiella hangoii population consisted of temporary cysts after $17 \mathrm{~d}$ in darkness, whereas values of 22 to $50 \%$ temporary cysts were found for Alexandrium ostenfeldii when responding to parasite-derived infochemicals (Toth et al. 2004). The high percentages of temporary cysts reported here are in the range previously reported for $S$. trochoidea in response to allelochemicals in laboratory setups, i.e. up to $84 \%$ (Fistarol et al. 2004). Even higher percentages of temporary cysts were reported for Prorocentrum minimum in response to temperature changes, i.e. up to $100 \%$, in a laboratory experiment by Grzebyk \& Berland (1996). Values from artificial laboratory conditions are generally higher than those reported from field conditions, even though such field studies are scarce. For instance, we observed around $20 \%$ temporary cysts in our cultures, even without any stressor, which could be related to culturing effects. The fraction that formed temporary cysts in natural populations of Heterocapsa triquetra, without any specific stressor tested, was lower than 1\% (Olli 2004). Garcés et al. (1998) observed 13 to $59 \%$ temporary cysts (within a $24 \mathrm{~h}$ period) when studying a natural population of Alexandrium taylori, with the highest values reported in the evening and at night when light intensities decrease. These values are in line with those reported here in response to low light intensities, i.e. $35 \%$ after $24 \mathrm{~h}$ (Fig. 2B), which suggests that results presented here could also be relevant outside laboratory conditions.

We suggest that temporary cyst formation in Scrippsiella trochoidea could be an effective mechanism for re- ducing population losses under conditions of low and fluctuating light intensities, which may be expected in future climate change scenarios (Kulmala et al. 2003). In such conditions, $S$. trochoidea may gain further advantages, as it would be able to overcome turbulence events, driving them to water depths where light is scarce.

\section{Effects of Acartia tonsa exposure}

In the present study, no temporary cysts (or hypnocysts) were formed in response to increasing densities of Acartia tonsa in either the direct or the indirect grazer exposure experiment. Previous reports on Scrippsiella trochoidea temporary cyst induction in response to various detrimental chemical signals (Fistarol et al. 2004, Toth et al. 2004, Tillmann et al. 2007, Tillmann \& Hansen 2009), indicate that $S$. trochoidea have receptors that respond to chemical signals. Acartia spp. have previously been reported to induce higher toxicity of Alexandrium minutum (Selander et al. 2006) and to induce morphological changes in Phaeocystis globosa (Long et al. 2007, Lundgren \& Granéli 2010) via released infochemicals. Although the studies cited above imply that $S$. trochoidea could be able to respond to infochemicals released from $A$. tonsa, the present study showed that this was not the case. The role of infochemical degradation in this lack of response can be excluded since no response was detected in the direct exposure experiment, in which $A$. tonsa was present and able to produce infochemicals throughout the duration of the experiment. Similarly, we can exclude the possibility that $S$. trochoidea is only affected by higher concentrations of infochemicals than other species are. This is because we also tested very high densities of $A$. tonsa $\left(200 \mathrm{l}^{-1}\right)$ in a small direct exposure experiment (data not shown), which lasted for $5 \mathrm{~d}$, but we did not observe any cyst induction in that experiment either.

Although findings on the occurrence of grazer-induced defence in phytoplankton are being increasingly reported in the international scientific literature, it is not a universal phenomenon, and evidently has not evolved for Scrippsiella trochoidea. Similarly, Van Donk et al. (1999) found prey specific responses to the cladoceran Daphnia; while some species reacted to infochemicals released from the grazer, others showed no response at all. This could depend on differences in the physiological state of different phytoplankton species (Van Donk et al. 1999).

\section{Defensive abilities of dinoflagellate cysts}

The potential defensive abilities of dinoflagellate cysts warrants some attention, as such abilities should confer some protection against predation to justify 
their utilisation by Scrippsiella trochoidea in response to grazer presence. Hypnocysts are rich in reserve material such as lipids and starch and therefore could constitute a good food source for potential grazers, provided that the grazers can break up, penetrate or dissolve the cyst wall (Persson 2000). However, hypnocysts have been shown to result in lower copepod ingestion rates and can even survive the gut passage of such grazers (Montresor et al. 2003). In the present study, hypnocysts were not observed as incubation only lasted $72 \mathrm{~h}$. Since zooplankton densities can vary on even shorter time scales than this, the goal of the grazer exposure experiment was to test direct and indirect effects of Acartia tonsa on temporary cysts. Such cysts, in contrast to hypnocysts, can survive short-term environmental fluctuations and quickly re-establish a motile vegetative state when favourable conditions reoccur (Anderson 1998).

As far as we know, there are no reports of temporary cysts being able to withstand digestion and surviving gut passage. Scrippsiella trochoidea is, however, able to withstand the effect of certain allelochemicals by forming temporary cysts, thus indicating that there is some chemical resistance by these cysts (Fistarol et al. 2004). Hypnocysts and temporary cysts share the feature of immobility and therefore sink to the bottom, which could be another potential defence strategy against copepods inhabiting and feeding in the water column (Sarjeant et al. 1987). Due to the mucilage, which often surrounds temporary cysts, they often form clumps or aggregates (Olli 2004). However, Jenkinson \& Biddanda (1995) suggest that adsorption of colloidal material, such as dissolved organic material (DOM), onto mucilaginous material could increase the availability of DOM to biological consumers. Seuront \& Vincent (2008) demonstrated that high viscosity induced by increased amounts of mucilaginous material did not mechanically hamper zooplankton grazing. Nevertheless, given the larger size of temporary cyst aggregates and their position in the water column, we argue that aggregate formation could in fact make temporary cysts less accessible to pelagic predators.

\section{Grazing experiment}

As shown in our results, the total ingestion rate of Acartia tonsa decreased as the percentage of temporary cysts in the diets increased. The highest ingestion reported, $0.65 \pm 0.04 \mu \mathrm{g} \mathrm{C} \mu \mathrm{g} \mathrm{C}^{-1} \mathrm{~d}^{-1}$, occurred in the vegetative cell treatment. This value was still about half that reported for A. granii (da Costa et al. 2008), but comparable to the ingestion rates reported for $A$. liljeborgii and A. clausi feeding on Scrippsiella trochoidea at the same carbon concentration $(800 \mu \mathrm{g} \mathrm{C}$ $\mathrm{l}^{-1}$ ) (Band-Schmidt et al. 2008). When taking the separate ingestions of vegetative cells and temporary cysts into consideration, it is evident that the decreased total ingestion rates observed in the mixture treatment and the temporary cyst treatment were the result of decreased ingestion of vegetative cells as these cells became fewer while the amount of temporary cysts in the diet increased (Fig. 3). In contrast, the ingestions on temporary cysts were non-significant in all treatments, even when the temporary cysts occurred in high concentrations, i.e. in the mixture treatment and the temporary cyst treatment.

It is outside the scope of this study to determine which mechanisms are behind the lower ingestion rates observed on temporary cysts. However, they could be related to (1) lower capture rates, caused by decreased encounter rates (swimming vegetative cells versus non-swimming temporary cysts), (2) post-capture rejection, or (3) an active food selection against temporary cysts, as has been discussed for hypnocysts (Montresor et al. 2003). Lower capture rates seem less likely since we had high food densities and used shaking tables to keep cells and cysts in suspension. We cannot exclude either post-capture rejection or food selection, nor can we exclude the possibility of grazer deterrent substances being produced by the temporary cysts as reasons for this rejection or non-selection.

The total daily rations observed in the present study ranged from $64.45 \pm 3.22 \%$ body $\mathrm{C} \mathrm{d}^{-1}$ on diets dominated by vegetative cells and $24.14 \pm 2.22 \%$ on diets dominated by temporary cysts. The daily carbon requirement for the basic metabolism of copepods is very variable but thought to be in the range of about $30 \%$ of body $\mathrm{C} \mathrm{d}^{-1}$ (Woolridge 1999). This would indicate that a diet dominated by vegetative cells can sustain basic Acartia tonsa metabolic requirements, whereas a diet containing a high percentage of temporary cysts cannot. However, carbon requirements for optimal egg production could be as high as $180 \%$ of body $\mathrm{C} \mathrm{d}^{-1}$ (Kiørboe et al. 1985), which indicates that even the ingestion rates reported in the vegetative cell treatment are less than optimal for $A$. tonsa.

Egg production rates vary almost linearly with ingestion rates (Kiørboe et al. 1985). Therefore, the lower rates of egg production in the mixture treatment and the temporary cyst treatment are in line with the lower ingestion observed in these treatments. The highest egg production rates reported for the vegetative cell treatment in the present study were lower than the optimal egg production rates of Acartia tonsa (Kiørboe et al. 1985), and lower than the egg production rates observed for A. clausii and A. liljeborgii feeding on Scrippsiella trochoidea at comparable carbon concentrations (Band-Schmidt et al. 2008). However, as shown by Band-Schmidt et al. (2008), egg production 
on the same diets can vary a great deal within species of Acartia. Furthermore, this does not affect our conclusion of decreased egg production in response to increased percentages of temporary cysts, as our treatments differed significantly from each other.

When zooplankton avoid feeding on phytoplankton with various properties, such as toxicity (Dutz 1998, Sopanen et al. 2006, Kozlowsky-Suzuki et al. 2009), non-preferred sizes (Berggreen et al. 1988), or low nutritional value (Jónasdóttir 1994), lower GGEs are often found, which demonstrates the advantage of allocating energy reserves to survival rather than reproduction when feeding on such phytoplankton (Sopanen et al. 2006). In the present study, GGE did not differ significantly between treatments. This is not surprising given that almost all of the ingested carbon in all treatments resulted from vegetative cells rather than temporary cysts. The GGEs observed here were lower than optimal values for Acartia on good food species, i.e. $28 \%$ (Dutz 1998) to 39\% (Kiørboe et al. 1985) for Rhodomonas baltica, but still notably higher than those reported on toxic species such as Prymnesium parvum, i.e. 1.5 to $3.3 \%$ (Sopanen et al. 2006).

Similar to egg production rates, faecal pellet production was lower on diets of temporary cysts compared to vegetative cells. This again reflects the lower ingestion in treatments with temporary cysts.

Even though ingestion rates, egg production and GGEs were suboptimal in the diets dominated by Scrippsiella trochoidea vegetative cells, they were still relatively high. However, pronounced effects on the entire ecosystem may occur in scenarios of low light intensities, when the percentage of temporary cysts increases. This is because of the marked decreased ingestion and egg production observed on diets dominated by temporary cysts. Although starvation requirements of $A$. tonsa are low (Kiørboe et al. 1985), they would most likely switch to alternative carbon sources, such as other phytoplankton species or microzooplankton to ensure a high rate of reproduction. Once $S$. trochoidea has established dominance, the result could be decreased transfer of energy to higher trophic levels in these ecosystems. Thus, the ability to form temporary cysts could help ensure bloom development and maintenance of $S$. trochoidea blooms.

\section{CONCLUSIONS}

As reflected in the lower ingestion, faecal pellet production, and egg production on diets dominated by temporary cysts compared to vegetative cells of Scrippsiella trochoidea, the grazing experiment indicated some defensive abilities of temporary cysts. Despite this, $S$. trochoidea does not seem to react with increased pro- duction of temporary cysts when exposed either directly or indirectly to increasing $A$. tonsa densities, at least not under the circumstances investigated here. Rather, induction of temporary cysts seems to be controlled by abiotic factors, such as decreased light intensity.

Although it is hard to extrapolate laboratory results to field conditions, we suggest that formation of temporary cysts is a useful mechanism to minimize population losses when Scrippsiella trochoidea is driven to water depths where light is scarce by, for instance, turbulence events. As reflected in the lower ingestion and egg production on diets dominated by temporary cysts, additional benefits, such as a shift in predation pressure towards other species, may arise in such situations. The occurrence of temporary cysts could contribute to the continued success and maintenance of $S$. trochoidea blooms, not only by reducing population losses, but also by providing an adaptive advantage over species unable to form temporary cysts.

Acknowledgements. We thank the staff at the Sven Lovén Centre for Marine Sciences, Gothenburg University, for supplying copepods. We are grateful to $M$. Clément at the Swedish Museum of Natural History for copepod identification. Four anonymous reviewers are thanked for valuable and constructive criticisms on an earlier version of the manuscript. We extend gratitude to the Linnaeus University for financial support.

\section{LITERATURE CITED}

Anderson DM (1997) Bloom dynamics of toxic Alexandrium species in the Northeastern U.S. Limnol Oceanogr 42:1009-1022

Anderson DM (1998) Physiology and bloom dynamics of toxic Alexandrium species, with emphasis on life cycle transitions. In: Anderson DM, Cembella AD, Hallegraeff GM (eds) Physiological ecology of harmful algal blooms. NATO ASI Series, Vol G 41. Springer-Verlag, Berlin, p 29-48

Anderson DM, Wall D (1978) Potential importance of benthic cysts of Gonyaulax tamarensis and G. excavata in initiating toxic dinoflagellate blooms. J Phycol 14:224-234

> Anderson DM, Kulis DM, Binder BJ (1984) Sexuality and cyst formation in the dinoflagellate Gonyaulax tamarensis: cyst yield in batch cultures. J Phycol 20:418-425

Band-Schmidt CJ, Pacheco-Chávez R, Hernández-Trujillo S (2008) Influence of phytoplankton diets on ingestion rate and egg production of Acartia clausii and A. lilljeborgii (Copepoda: Calanoida) from Bahía de La Paz, Gulf of California. Hydrobiologica 18:133-140

Berggreen U, Hansen B, Kiørboe T (1988) Food size spectra, ingestion and growth of the copepod Acartia tonsa during development: implications for determination of copepod production. Mar Biol 99:341-352

Cervetto G, Gaudy R, Pagano M, Saint-Jean L, Verriopoulos G, Arfi R, Leveau M (1993) Diel variations in Acartia tonsa feeding, respiration and egg production in a Mediterranean coastal lagoon. J Plankton Res 15:1207-1228

> da Costa RM, Pereira LCC, Fernández F (2008) Effects of toxic Alexandrium minutum on the feeding and survival rates of 
pelagic marine copepods Acartia grani and Euterpina acutifrons. Hydrobiologia 614:55-63

> Doucette GJ, Cembella AD, Boyer GL (1989) Cyst formation in the red tide dinoflagellate Alexandrium tamarense (Dinophyceae): effects of iron stress. J Phycol 25:721-731

Dutz J (1998) Repression of fecundity in the neritic copepod Acartia clausi exposed to the toxic dinoflagellate Alexandrium lusitanicum: relationship between feeding and egg production. Mar Ecol Prog Ser 175:97-107

Figueroa RI, Bravo I, Garcés E, Ramilo I (2006) Nuclear features and effect of nutrient on Gymnodinium catenatum (Dinophyceae) sexual stages. J Phycol 42:67-77

Fistarol GO, Legrand C, Rengefors K, Granéli E (2004) Temporary cyst formation in phytoplankton: a response to allelopathic competitors? Environ Microbiol 6:791-798

Frost BW (1972) Effects of size and concentration of food particles on the feeding behavior of the marine planktonic copepod Calanus pacificus. Limnol Oceanogr 17:805-815

Garcés E, Delgado M, Maso M, Camp J (1998) Life history and in situ growth rates of Alexandrium taylori (Dinophyceae, Pyrrophyta). J Phycol 34:880-887

Garcés E, Masó M, Camp J (2002) Role of temporary cysts in the population dynamics of Alexandrium taylori (Dinophyceae). J Plankton Res 24:681-686

Garcés E, Bravo I, Vila M, Figueroa I, Maso M, Sampedro N (2004) Relationship between vegetative cells and cyst production during Alexandrium minutum bloom in Arenys de Mar harbour (NW Mediterranean). J Plankton Res 26: 637-645

Grzebyk D, Berland B (1996) Influences of temperature, salinity and irradiance on growth of Prorocentrum minimum (Dinophyceae) from the Mediterranean Sea. J Plankton Res 18:1837-1849

Guillard RRL (1975) Culture of phytoplankton for feeding marine invertebrates. In: Smith WL, Chanley MH (eds) Culture of marine invertebrate animals. Plenum Press, New York, NY, p 26-60

> Guillard RRL, Hargraves PE (1993) Stichochrysis immobilis is a diatom, not a chrysophyte. Phycologia 32:234-236

Hansson LA (1996) Behavioural response in plants: adjustment in algal recruitment induced by herbivores. Proc Biol Sci 263:1241-1244

Hardeland R (1994) Induction of cyst formation by low temperature in the dinoflagellate Gonyaulax polyedra Stein: dependence on circadian phase and requirement of light. Experientia 50:60-62

Hessen DO, van Donk E (1993) Morphological changes in Scenedesmus induced by substances released from Daphnia. Arch Hydrobiol 127:129-140

> Hieronymi M, Macke A (2010) Spatiotemporal underwater light field fluctuations in the open ocean. J Eur Opt Soc Rapid Publ 5:10019S

- Huntley ME, Lopez MDG (1992) Temperature-dependent production of marine copepods: a global synthesis. Am Nat 140:201-242

Imai I (1989) Cyst formation of the noxious red tide flagellate Chattonella marina (Raphidophyceae) in culture. Mar Biol 103:235-239

> Jang MH, Ha K, Joo GJ, Takamura N (2003) Toxin production of cyanobacteria is increased by exposure to zooplankton. Freshw Biol 48:1540-1550

> Jenkinson IR, Biddanda BA (1995) Bulk-phase viscoelastic properties of seawater: relationship with plankton components. J Plankton Res 17:2251-2274

> Jensen MO, Moestrup O (1997) Autoecology of the toxic dinoflagellate Alexandrium ostenfeldii: life history and growth at different temperatures and salinities. Eur J Phycol 32:9-18
Jónasdóttir SH (1994) Effects of food quality on the reproductive success of Acartia tonsa and Acartia hudsonica: laboratory observations. Mar Biol 121:67-81

Kiørboe T, Møhlenberg F, Hamburger K (1985) Bioenergetics of the planktonic copepod Acartia tonsa: relation between feeding, egg production and respiration, and composition of specific dynamic action. Mar Ecol Prog Ser 26:85-97

Kozlowsky-Suzuki B, Koski M, Hallberg E, Wallén R, Carlsson P (2009) Glutathione transferase activity and oocyte development in copepods exposed to toxic phytoplankton. Harmful Algae 8:395-406

Kulmala M, Suni T, Lehtinen KEJ, Dal Maso M and others (2003) A new feedback mechanism linking forests, aerosols, and climate. Atmos Chem Phys Discuss 3: 6093-6107

> Long JD, Smalley GW, Barsby T, Anderson JT, Hay ME (2007) Chemical cues induce consumer-specific defenses in a bloom-forming marine phytoplankton. Proc Natl Acad Sci USA 104:10512-10517

> Lundgren V, Granéli E (2010) Grazer induced defence in Phaeocystis globosa (Prymnesiophyceae): influence of different nutrient conditions. Limnol Oceanogr 55: 1965-1976

Marshall HG, Egerton TA (2009) Phytoplankton blooms: their occurrence and composition within Virginia's tidal tributaries. Va J Sci 60:149-164

> Miller CA, Roman MR (2008) Effects of food nitrogen content and concentration on the forms of nitrogen excreted by the calanoid copepod, Acartia tonsa. J Exp Mar Biol Ecol 359:11-17

Montresor M, Nuzzo L, Mazzocchi MG (2003) Viability of dinoflagellate cysts after the passage through the copepod gut. J Exp Mar Biol Ecol 287:209-221

Nagasaki K, Yamaguchi M, Imai I (2000) Algicidal activity of a killer bacterium against the harmful red tide dinoflagellate Heterocapsa circularisquama isolated from Ago Bay, Japan. Bull Jpn Soc Sci Fish 66:666-673

Olli K (2004) Temporary cyst formation of Heterocapsa triquetra (Dinophyceae) in natural populations. Mar Biol 145: 1-8

Persson A (2000) Possible predation of cysts - a gap in the knowledge of dinoflagellate ecology? J Plankton Res 22: 803-809

Pfiester LA, Anderson DM (1987) Dinoflagellate reproduction. In: Taylor FJR (ed) The biology of dinoflagellates. Botanical monographs, Vol 21. Blackwell Scientific Publications, Oxford, p 611-648

> Purcell JE, White JR, Roman MR (1994) Predation by gelatinous zooplankton and resource limitation as potential controls of Acartia tonsa copepod populations in Chesapeake Bay. Limnol Oceanogr 39:263-278

> Rengefors K, Anderson DM (1998) Environmental and endogenous regulation of cyst germination in two freshwater dinoflagellates. J Phycol 34:568-577

> Rengefors K, Karlsson I, Hansson LA (1998) Algal cyst dormancy: a temporal escape from herbivory. Proc Biol Sci 265:1353-1358

Rintala JM, Spilling K, Blomster J (2007) Temporary cyst enables long-term dark survival of Scrippsiella hangoei. Mar Biol 152:57-62

Sarjeant WAS, Lacalli T, Gaines G (1987) The cysts and skeletal elements of dinoflagellates: speculations on the ecological causes for their morphology and development. Micropaleontology 33:1-36

Selander E, Thor P, Toth G, Pavia H (2006) Copepods induce paralytic shellfish toxin production in marine dinoflagellates. Proc Biol Sci 273:1673-1680 
Seuront L, Vincent D (2008) Increased seawater viscosity, Phaeocystis globosa spring bloom and Temora longicornis feeding and swimming behaviours. Mar Ecol Prog Ser 363:131-145

Sgrosso S, Esposito F, Montresor M (2001) Temperature and daylength regulate encystment in calcareous cyst-forming dinoflagellates. Mar Ecol Prog Ser 211:77-87

Sopanen S, Koski M, Kuuppo P, Uronen P, Legrand C, Tamminen T (2006) Toxic haptophyte Prymnesium parvum affects grazing, survival, egestion and egg production of the calanoid copepods Eurytemora affinis and Acartia bifilosa. Mar Ecol Prog Ser 327:223-232

Tang KW (2003) Grazing and colony size development in Phaeocystis globosa (Prymnesiophyceae): the role of a chemical signal. J Plankton Res 25:831-842

Tillmann U, Hansen PJ (2009) Allelopathic effects of Alexandrium tamarense on other algae: evidence from mixed growth experiments. Aquat Microb Ecol 57:101-112

Tillmann U, John U, Cembella A (2007) On the allelochemical potency of the marine dinoflagellate Alexandrium ostenfeldii against heterotrophic and autotrophic protists. J Plankton Res 29:527-543

Toth GB, Noren F, Selander E, Pavia H (2004) Marine dinoflagellates show induced life-history shifts to escape parasite

Editorial responsibility: Urania Christaki, Wimereux, France infection in response to water-borne signals. Proc Biol Sci 271:733-738

Valderrama JC (1995) Method of nutrient analysis. In: Hallegraeff GM, Anderson DM, Cembella AD (eds) Manual of harmful marine microalgae. IOC and guides, UNESCO, p 251-568

Van Donk E, Lürling M, Lampert W (1999) Consumerinduced changes in phytoplankton: inducibility, costs, benefits, and the impact on grazers. In: Tollrian R, Harvell CD (eds) The ecology and evolution of inducible defenses. Princeton University Press, Princeton, NJ, p 89-103

Wang ZH, Qi YZ, Yang YF (2007) Cyst formation: an important mechanism for the termination of Scrippsiella trochoidea (Dinophyceae) bloom. J Plankton Res 29:209-218

Woolridge T (1999) Estuarine zooplankton community structure and dynamics. In: Allanson BR, Baird D (eds) Estuaries of South Africa. Cambridge University Press, Cambridge, $p$ 141-166

Xiao Y, Qi Y, Wang Z, Lu S (2001) The relationship between Scrippsiella trochoidea red tide and cysts in the Daya Bay. Mar Sci Haiyang Kexue 25:50-54

Zonneveld KAF, Susek E (2007) Effects of temperature, light and salinity on cyst production and morphology of Tuberculodinium vancampoae (the resting cyst of Pyrophacus steinii). Rev Palaeobot Palynol 145:77-88

Submitted: November 24, 2010; Accepted: January 26, 2011 Proofs received from author(s): April 18, 2011 